\title{
THE SUBMICROSCOPIC STRUCTURE OF CAPRINE ARTICULAR CARTILAGE IN ONTOGENY
}

\author{
D. HORKÝ* \\ Department of Anatomy, Histology and Embryology \\ University of Veterinary and Pharmaceutical sciences \\ 61242 Brno, Czech Republic
}

Received July 20, 1992

\begin{abstract}
Horký D.: The submicroscopic structure of caprine articular cartilage in ontogeny. Acta vet., Brno, 63, 1994: 41-48.

Articular cartilage from the hip joints of goats was studied in foetuses at 56 days after fertilization and in animals aged 33 and 77 days and 4 and 6 years.

At 56 days after fertilization, the cartilage surface was covered with a chondrosynovial membrane. Underneath, parallel to the surface, there was a network of collagen fibrils with small bundles of aperiodic filaments amongst them. Chondroblasts were reminiscent of fibroblast Both the cells and intercellular matrix in all the layers had appearances usual for this stage of development.

At 33 and 77 days after birth, chondrocytes in the surface and middle layers were very rich in organelles, which is a feature characteristic of the synthesis of intercellular matrix. The surface layer contained collagen fibrils with periodicity. The deep layer chondrocytes contained glycogen deposits. The pericellular matrix was well developed.

In adult animals, the surface of articular cartilage showed intact regions interspersed with areas of fibrillar appearance. Typical collagen fibres crossed at right angles and their mass prevailed over the ground amorphous substance. Chondrocytes of the deep layer contained diffusely distributed glycogen granules and large lipid vacuoles.
\end{abstract}

\section{Submicroscopic structure, articular cartilage, goat}

Articular cartilage is derived from mesenchyma during the skeletal development as a part of the cartilaginous blastema of the bone rudiment. This rudiment is restructured by ossification into the definite bone while the developed cartilage is adapted to facilitate locomotion of the organism. During ontogeny, the major components of cartilage, i. e., chondrocytes and intercellular matter, undergo a differentiation process leading to the development of articular cartilage in the prenatal period followed by further changes in the postnatal period. Together this is called the maturation process and is determined by genetical, endocrinological, nutritional and, particularly in the postnatal period, environmental factors (Ghadially 1978, 1982; Perrin et al. 1978; Horký 1980, 1986, 1989, 1991b, c, d; B o z děch et al. 1990). Apart from species-specific characteristics, morphological changes are largely due to aging. They have been described in adult mice (Silb e r g e r et al. 1976), rabbits (B arn et t et al. 1963; Davies et al. 1962), dogs (Lust et al. 1972; Lust and Sherman 1973; Wiltberger and Lust 1975; Clark 1991; Greisen et al. 1982), cattle (Horký 1983, 1987), pigs (Grondalen 1974c, f; Nakano et al. 1979a, b; Bhatnagar etal. 1981; Horký 1991f) and man (Ghadially and Roy 1969; Ghadially 1978, 1982; Horký 1980; Bozděch et al. 1990).

The review presented above is in sharp contrast with the lack of literature data on the articular cartilage in small ruminants. Only a few papers have been published dealing with the selected areas of articular cartilage and their functions (B room and Poole 1982), allotransplants of articular cartilage (Hes s e and Hes se 1982) or problems related to articular lubrication ( Hills 1989, 1990). No description of articular cartilage with regard to the distribution and arrangement of chondrocytes and the appearance of intercellular matrix has been found for this animal category. Therefore, a decision was made to provide the missing data on articular cartilage with the use of goats in ontogeny as model animals.

\section{Materials and Methods}

Samples of articular cartilage were taken from femoral heads of 10 animals. Foetuses were sampled at 56 days after fertilization, animals after birth were 33 and 77 days and 4 and 6 years old. For trasmission electron microscopy, strips of the tissue $(1 \times 1 \times 2 \mathrm{~mm})$ were immediately fixed in $300 \mathrm{mmol} / 1$ or $400 \mathrm{mmol} / /$ glutaraldehyde in phosphate buffer at $\mathrm{pH} 7.4$ for $240 \mathrm{~min}$. They were subsequently washed in 4 baths of $0.01 \mathrm{M}$ phosphate buffer, $\mathrm{pH} 7.4$,

* Present address: Department of Histology and Embryology, Faculty of Medicine, Masaryk University, $66243 \mathrm{Brno}$ 
$30 \mathrm{~min}$ each. This was followed by fixation with $40 \mathrm{mmol} / \mathrm{O} \mathrm{OsO}$ in phosphate buffer at $\mathrm{pH} 7.4$ for $60 \mathrm{~min}$. Dehydration, immersion and embedding in Durcupan ACM were carried out using standard methods. Ultrathin sections were cut in an Ultracut Reichert ultramicrotome, stained with lead citrate alone or with uranyl acetate followed by lead citrate. The sections were examined and photographed in a Tesla BS 500 electron microscope. The embedded blocks were also used to make semithin sections for light microscopy. These were stained with methylene blue and Azure II.

For scanning electron microscopy, samples of articular cartilage $(5 \times 5 \mathrm{~mm})$ included a part of subchondral bone. They were first washed in 3 changes of physiological saline, 15 min each, then fixed in $10 \%$ formaldehyde or glutaraldehyde for 10 to 14 days. The fixed tissue was dehydrated by drying at the critical point, shadowed with gold in a Balzers apparatus and examined and photographed in a scanning electron microscope (Stereocan, Cambridge).

\section{Results}

Ultrastructure of the surface layer

At 56 days after fertilization, chondroblasts of the surface layer were elongated or spindle-shaped cells. They were located parallel to the surface and their size was up to 10-12 $\mu \mathrm{m}$ by $4 \mu \mathrm{m}$. The nucleus matched the cell in shape (Plate V, Fig. 1). A nucleolus of reticular type was a regular finding. Chromatin was arranged into karyosomes found near the nuclear envelope. The cytoplasm contained, in addition to occasional dilated cisternae of granular endoplasmic reticulum (ER) and mitochondria, small amounts of glycogen granules. The cell membrane sent out few short projections. The pericellular matrix was developed in the region attached to the middle layer, while near the surface the chondrocyte membrane came to contact with the intercellular matrix (Fig. 1). The pericellular matrix consisted of ground amorphous substance and a low amount of aperiodic filaments. The intercelullar matrix included, apart from aperiodic fibrils, occasional collagen fibrils. A developing chondrosynovial membrane could be seen on the cartilage surface. It was formed by short aperiodic fibrils, arranged in a network, and the amorphous substance. Apart from these structures, bundles of aperiodic fibrils, 0.2 to $0.3 \mu \mathrm{m}$ thick, were located about 1 to $2 \mu \mathrm{m}$ under the synovial membrane. The aperiodic fibrils extending from these bundles became a part of the intercellular matrix (Fig. 1). About $1 \mu \mathrm{m}$ below the surface there were remnants of cell organelles.

At 33 days after birth, the ultrastructure of surface articular cartilage showed considerable changes. Although neither chondrocytes nor their nuclei differed much from those at the earlier stage, the cytoplasm was markedly different (Fig. 2). It contained a large amount of granular ER cisternae filled with medium dense material, numerous small, smooth vesicles derived from the Golgi apparatus, transmission vacuoles and minute mitochondria. Small aggregates of glycogen granules were randomly situated amongst the organelles (Fig. 2). The cell membrane was smooth in the upper part near the surface, while its lower surface sent out short $(0.5$ to $0.8 \mu \mathrm{m})$ thick, branched projections.

The pericellular matrix was continuous with the intercellular matrix. The lower cell surface came to contact directly with the intercellular matrix containing typical collagen fibrils. The upper part of the cell surface was in contact with a zone of pericellular matrix of varying width which also included aperiodic fibrils.

The surface of articular cartilage was covered with a chondrosynovial membrane; below this, there were areas of densely accumulated aperiodic fibril (Plate V, Fig. 2). Small bundles of these fibrils were also located in deeper parts of the intercellular matrix.

In adult animals, the surface layer of articular cartilage was characterized by a thick zone, up to $5 \mu \mathrm{m}$, with only occasional presence of chondrocytes (Plate VI, Fig. 3). These did not differ in morphology from the cells observed at the previous stages. Typical collagen fibres 
prevailed in this layer. They were assembled into bundles running parallel to the surface or crossing at right angles (Fig. 3).

The ground amorphous substance contained randomly distributed dark components (about $0.1 \mu \mathrm{m})$, probably cell detritus.

The chondrosynovial membrane, thin but compact, matched exactly the surface topography (Fig. 3). The finely meshed or particulate material filling surface depressions was similar in composition to the chondrosynovial membrane (Fig. 3).

\section{Ultrastructure of the middle layer}

At 56 days after fertilization, chondrocytes of this layer were ovoid cells, up to $10 \mu \mathrm{m}$ by $5 \mu \mathrm{m}$ in size. Pairs or groups of three were located in lacunae (Plate VI, Fig. 4). Spaces between them were filled with intercellular matrix and formed a septum.

Nucleus was ovoid, chromatin was aggregated into karyosomes situated along the nucleus circumference or located around the nucleolus of reticular type (Fig. 4). One or two nucleoli were a regular finding.

Cisternae of granular ER, often dilated, were filled with finely fibrillar material (Fig. 4). The cytoplasm further contained transport vacuoles, mitochondria and clusters of glycogen.

The cell membrane was almost smooth on the inward surfaces of chondrocytes in lacunae, while the outward surfaces were broken into many short projections extending into the pericellular matrix (Fig. 4). This was well developed with the usual structure and surrounded the chondrocytes from the outside. The intercellular matrix had loose texture consisting of ground amorphous substance, which prevailed, and loose meshwork of aperiodic collagen fibrils. Small bundles of aperiodic filaments were seen as part of the septa between chondrocytes enclosed in lacunae and in the intercellular matrix. (Fig. 4).

At 33 and 77 days after birth, the middle layer showed some differences from the prenatal stage, particularly in the ultrastructure of chondrocytes.

The chondrocytes were pyramidal in shape (roughly triangular on section) and were located in pairs in lacunae (Plate VII, Fig. 5). The nucleus matched the cell in shape, chromatin formed large aggregates. A reticular-type nucleolus was always present. The zonula nucleum limitans was not observed.

The cytoplasm was rich in organelles which were involved in the production of intercellular matrix. The granular ER consisted of numerous long cisternae, arranged in tiers, occupying a large part of cytoplasm (Fig. 5). The cisternae were filled with medium electron dense material. The space amongst them contained mitochondria, transport vacuoles and, occasionally, large deposits of glycogen. The Golgi apparatus was regularly found close to the nucleus (Fig. 5).

The perinuclear matrix was, to a limited extent, attached to the inward surfaces of cells. The most of the chondrocyte surface was in contact with the intercellular matrix. The septum between the cells in lacunae was made of aperiodic collagen fibres. Typical collagen fibrils with periodicity were another component of the intercellular matrix.

In adult animals, the middle layer of articular cartilage shows the evidence of maturation of chondrocytes and intercellular matrix in terms of morphology, ultrastructure and function.

Chondrocytes appeared as elongated pyramids $12-14 \mu \mathrm{m}$ by $5 \mu \mathrm{m}$ in size. The nucleus shape matched that of the cell. Chromatin, aggregated into several large clusters, formed an almost continuous lining at the nuclear envelope. The remaining area of the nucleus was markedly light.

The cytoplasm at this stage had a much higher content of organelles responsible for protein synthesis than was seen in the earlier periods. These intracytoplasmic organelles, in 
large groups, encircled the nucleus coming to contact with the outer membrane of the nuclear envelope (Plate VII, Fig. 6). Glycogen, in small clusters, was diffusely distributed at the cell periphery.

The cell membrane was almost smooth, with occasional wide and short projections extending into the pericellular matrix. This formed a wide layer $(0.5$ to $0.8 \mu \mathrm{m})$ filled with densely accumulated aperiodic fibres running parallel to the cell membrane, presenting as a dense ,coating“ of the chondrocyte. Transition from the pericellular to intercellular matrix was not clear. The intercellular matrix was largely composed of typical collagen fibrils arranged concentrically around the pericellular matrix, thus providing a „basket“ for each chondrocyte'(Fig. 6). The ground amorphous substance included dark components (0.1 to $0.2 \mu \mathrm{m}$ ) regarded as detritus from disintegrated cells (Fig. 6).

\section{Ultrastructure of the deep layer}

At 33 and 77 days after birth, the deep layer was distinctly defined (Plate VIII, Fig. 7). Chondrocytes had their characteristic sickle-shaped apperance and a size of 15-20 $\mu \mathrm{m}$ by 4-5 $\mu \mathrm{m}$. They were located close together in pairs but not enclosed in lacunae. Both the nucleus and nucleolus showed the usual apperance and arrangement. Numerous cisternae of granular ER were narrow, situated in tiers (Fig. 7). The cisternae were usually found near the cell membrane; their occurence in other parts of the cytoplasm was a rare finding. Small mitochondria, transport vacuoles and numerous minute, smooth vesicles belonging to the agranular ER or derived from the Golgi apparatus were observed. Large deposits of glycogen often occupied a considerable part of the cytoplasm. Glycogen was closely related to lipid vacuoles (Fig. 7).

The cell membrane showed only occasional short processes $(0.5 \mu \mathrm{m})$ extending into the pericellular matrix of usual apperance, but varying in width, surrounding each chondrocyte (Fig. 7). The intercellular matrix did not differ from that of the middle layer at the same stage of development.

In adult animals, the deep layer of articular cartilage contained chondrocytes, $8-10 \mu \mathrm{m}$ by $5 \mu \mathrm{m}$, located singly in the intercellular matrix (Plate VIII, Fig. 8). The nuclear apparatus was identical to that in the middle layer chondrocytes. The zonula nucleum limitans was developed. A nucleolus, if seen, was of reticular type. The granular ER was present in a limited amount but mitochondia were numerous and had the usual size and structure. Neither intracytoplasmic filaments, transport vacuoles nor lysosomes were present. Abundant glycogen granules were scattered throughout the cytoplasm. Large lipid vacuoles were regularly seen (Fig. 8).

The cell membrane produced projections (up to $1 \mu \mathrm{m}$ long) which penetrated into the intercellular matrix because the pericellular matrix was only a narrow lining of the cell or was missing altogether (Fig. 8). Collagen fibrils with periodicity were arranged in various directions in the pericellular matrix. Only occasionally were groups of aperiodic fibrils seen at the chondrocyte cell membrane (Fig. 8).

\section{Discussion}

The differentiation of articular cartilage from mesenchyma during skeleton development in various mammalian species, including man, has been well described in the literature (Ghadially 1983; Horký 1980, 1983, 1986, 1987, 1991a, b, d). Smooth movement of the synovial joint is facilitated by the surface layer of cartilage, while the middle and deep layers play important roles in resistance to loads and the distribution of pressure forces to the subchondral bone. 
Chondrocytes in the surface layer produce ground amorphous substance and intercellular matrix (Sheld on and K imball 1962) responsible for the mechanical operation of cartilage (Freeman and Kempson 1973).

This study showed that in the goat before birth, like in other mammalian species, the articular cartilage consists of three distinct layers (Palf rey and D a vies 1966; Horký 1986, 1987, 1989, 1991a, b).

The development of the chondrosynovial membrane in the goat during ontogeny was in agreement with the observations of Wolf (1975), McConaill (1951), Weis s et al. (1968), S tockwell and Meachim (1979) as well as with our previous findings made in other mammalian species in various ontogenic periods (Horky 1980, 1986, 1987, 1989, 1991a,b). The view held by Mc Cut chen (1966) and Maroud as (1973) that the chondrosynovial membrane develops by the ultrafiltration of synovial fluid through the surface cartilage layers seems questionable. Our earlier investigations suggest that, in the development of this structure, a major role is played by aperiodic filaments which are arranged in bundles on or closely under the cartilage surface and which do not polymerize to form typical collagen fibrils. This layer, thick in the prenatal period, grows thinner with age. It is responsible for smooth gliding movement of articular surfaces which are often subject to enormous loads (Chappuis et al. 1983; Swann et al. 1984; Hills 1989). Lubricating substance, which is produced by synovialocytes, reduces the coefficent of friction to 0.01 . This value has never been attained with any artificial material.

During cartilage maturation, the chondrosynovial membrane grows thinner, while collagen fibres in the intercellular matrix increase in quantity. These collagen fibres are responsible for the degree of elasticity while the ability to resist to pressure forces is due to the presence of proteoglycans in the ground amorphous substance. This view was fully supported by our findings of an increased number of collagen fibrils and the perpendicular pattern of their arrangement in the surface layer. An even more pronounced pattern was seen in bovine cartilage (Horky 1983). Our observations of the surface layer of caprine cartilage during ontogeny are in good agreement with those of Bloe bau m and Wils on (1980) and Clark (1990). In the prenatal and early postnatal periods in the goat as well as in other mammalian species (Horký 1986, 1987, 1989, 1991a, b, d), the surface layer of catrilage has always included bundles of aperiodic fibrils arranged at some distance under the surface or immediately under the superficial layer of chondrocytes. It was distinctly seen that the bundles disentangled and individual fibrils became parts of the surrounding intercellular matrix. It is noteworthy that other authors did not pay attention to this structure even if, in our opinion, it plays a major role in formation of the fibrillar component of cartilage.

The middle layer in the caprine prenatal period and after birth did not show any marked differences from the corresponding layers seen in other mammalian species at these stages of development (Davies etal. 1962; Gardner and O'Rahilly 1983; Gilmore and Palfrey 1988; Horký 1989; B ozděch et al. 1990). In contrast to the cited authors, our observations of this layer showed large amounts of glycogen in all the studied periods, with the exception of cartilage at 56 days after fertilization. It has been reported ( $\mathrm{Gh}$ a d i ally 1983) that the amount of glycogen need not be directly proportional to the synthetic activity of chondrocytes. An unusual appearance of the middle layer of articular cartilage, as regards the pericellular and intercellular matrix, was found in goats 4 and 6 years old. A similar finding has been made only in the pericellular matrix of articular cartilage in the adult pig ( Horky 1992). The intercellular matrix with densely distributed collagen fibrils forming ,,baskets“ around chondrocytes was observed in the articular cartilage of adult cattle (Horký 1983) and man (Horký 1980). This arrangement is probably associated with the distribution of pressure forces in deep cartilage layers and with the synthesizing activity of chondrocytes. 
The deep layer showed differences between immatured ( 33 and 77 days after birth) and matured (4 and 6 years) caprine articular cartilage. The general structure of this layer, however, corresponded to those of other mammals at comparable stages of development. This is particularly true for the deep layer of articular cartilage in the tidemark region in adult and old individuals (Broom and Poole 1982; Ghadially 1983).

\section{Submikroskopická struktura kloubní chrupavky kozy v ontogenezi}

Byla studována artikulární chrupavka 10 kycelních kloubů jedinců ve stárí 56 dní po oplození, 33 a 77 dní po narození a dospělých zvî́at stárí 4 a 6 rokủ.

V období 56 dní po oplození je na povrchu chrupavky již vytvơ̌ena chondrosynoviální membrána. Pod ní paralelně s povrchem probíhají mezi sítovitě uspơ̌ádanými kolagenními fibrilami svazečky aperiodických filament. Chondroblasty se nápadně podobají fibroblastủm. Jak buňky, tak intercelulární hmota ostatních vrstev mají uspớádání obvyklé pro toto vývojové období.

V období 33, resp. 77 dní po narození obsahují chondrocyty jak povrchové, tak zejména střední vrstvy velké množství organel, charakteristických pro syntézu intercelulární hmoty. $\mathrm{V}$ její povrchové vrstvě se vyskytují kolagenní fibrily s periodicitou. $\mathrm{V}$ chondrocytech hluboké vrstvy jsou uložena depozita glykogenu. Pericelulární matrix je žretelně vytvơ̌ena.

Na povrchu kloubní chrupavky dospělých jedincủ stárí 4-6 rokủ se kromě intaktního povrchu nachází úseky počínající fibrilace. Typické kolagenní fibrily se křiží pod pravými úhly a převažují nad základní hmotou amorfní.

Chondrocyty hluboké vrstvy obsahují kromě difuzně roztroušených granul glykogenu velké tukové vakuoly.

\section{Субмикроскопичөская структура суставного хряща козы в онтогөнезисө}

Проводили исследования суставного хряща 10 тазобедренных суставов особей в возрасте 56 суток после оплодотворения, 33 и 77 суток после рождения и взрослых животных в возрасте 4 и 6 лет.

В возрасте 56 суток после оплодотворения на поверхности хряща уже обраована хондросиновиальная мембрана. Под ней параллельно к поверхности проходят между сетевидно расположенными клейдающими фибриллами пучки апериодических нитей. Хондробласты весьма похожи на фобробласты. Расположениеклеток, а также межклеточного вещества остальных слоев обычно для данного периода развития.

В период 33 или 77 суток после рождения хондроциты - не только поверхностные, но и в особенности средние слои - содержат болшое количество органелл, характерных для синтеза межклеточного вещестбва. В его поверхностном слое встречаются клейдающие фибриллы с периодичностью. В хондроцитах глубокого слоя расположены отложения гликогена. Перицеллюлярный ростковый слой четко выделен.

На поверхности суставного хряща взрослых особей в возрасте 4-6 лет помимо интактной поверхности встречаются участки начинающейся фибрилляции. Характерные клейдающие фибриллы перекрещиваются под прямым углом, преобладая над аморфным веществом.

Хондроциты глубокого слоя помимо дифузно рассеянныхгранулей гликогена содержат крупные жировые вакуоли.

\section{References}

BARNETT, C. H.-COCHRANE, W.-PALFREY, A. J.: Age changes in articular cartilage of rabbits. Ann. Rheum. Dis., 22, 1963: 389-400.

BHATNAGAR, R.-CHRISTIAN, R. G.-NAKANO, T.-AHERNE, F. X.-THOMPSON, J. R.: Age related chan- 
ges and osteochondrosis in swine articular and epiphyseal cartilage: Light and electron microscopy. Can. J. Comp. Med., 45, 1981: 188-195.

BLOEBAUM, R. D.-WILSON, A. S.: The morfology of the surface of articular cartilage in adult rats. Am. J. Anat., 131, 1980: 333-346.

BOZDËCH, Z.-HORKÝ, D.-JANEČEK, M.: Chrupavka a synoviální tkán̆ lidského kloubu. Acta Fak. Med. Univ. Masaryk., 1990: 1-150.

BROOM, N. D.-POOLE, C. A.: A functional morphological study of the tidemark region of articular cartilage maintained in a non-viable physiological condition. J. Anat., 135, 1982: 65-82.

CLARK, J. M.: The organisation of collagen fibrils in the superficial zones of articular cartilage. J. Anat., 171, 1990: 117-130.

CLARK, J. M.: Variation of collagen fiber alignment in a joint surface: a scanningf electron microscope study of the tibial plateau in dog, rabbit, and man. J. Orthop. Res., 9, 1991: 246-257.

DAVIES, D. V.-BARNETT, C. H.-COCHRANE, W.-PALFREY, A. J.: Electron microscopy of articular cartilage in the young adult rabbit. Ann. rheum. Dis., 21, 1962: 11-22.

FREEMAN, M. A. R.-KEMPSON, G. E.: Load carriage. In: Adult articular cartilage, pp. 228-246, M. A. R. Freeman (ed.), Alden Press, Oxford, Great Britain, 1973.

GARDNER, E.-O'RAHILLY, R.: The early development of the knee joint in staged human embryos. J. Anat. (London), 102, 1968: 289-299.

GHADIALLY, F. N.: Fine structure of joints. In: The joints and synovial fluid (ed. Sokoloff, L.) pp. 105-176, New York, Academia Press Inc. 1978.

GHADIALLY, F. N.: Structure and function of articular cartilage. Clin. rheum. Dis., 7, 1981: 3-28.

GHADIALLY, F. N.: Ultrastructural pathology of the cell and matrix. London, Butterworths, 1982, 20-45.

GHADIALLY, F. N.: Fine structure of synovial joints. Butterworths, London, 1983.

GHADIALLY, F. N.-ROY, S.: Ultrastructure of synovial joints in health and disease. Butterworths. London, 1969.

GILMORE, R. ST. C.-PALFREY, A. J.: Chondrocyte distribution in the articular cartilage of human femoral condyles. Am. J. Anat., 157, 1988: 23-31.

GREISEN, H. A.-SUMMERS, B. A.-LUST, G.: Ultrastructure of the articular cartilage and synovium in the early stages of degenerative joint disease in canine hip joints. Am. J. Vet. Res., 43, 1982: 1963-1971.

GRONDALEN, T.: Osteochondrosis and arthrosis in pigs. III. A comparison of the incidence in young animals of the Norwegian Landrace and Yorkshire breeds. Acta Vet. Scand., 15, 1974a: 43-52.

GRONDALEN, T.: Osteochondrosis, arthrosis and leg weakness in pigs. Nord. Vet. Med., 26, 1974b: 534-537.

HILLS, B. A.: Oligolamellar lubrication of joints by surface active phospholipid. J. Rheumatol., 16, 1989: 82-91.

HILLS, B. A.: Oligolamellar nature of the articular surface. J. Rheumatol., 17, 1990: 340-356.

HESSE, W.-HESSE, I.: Elektronenmikroskopische Untersuchungen über die Einheilung konservierter und nicht konservierter allogener Gelenkknorpeltransplantate. Z. Orthop., 120, 1982: 641-649.

HORKÝ, D.: Submicroscopic structure of the human joint cartilage. Acta vet. Brno, 49, 1980: 145-176.

HORKYY, D.: Ontogenic development of the ultrastructure of bovine joint cartilage. Acta vet. Brno, 52, 1983: 103-130.

HORKÝ, D.: Ultrastructure of bovine articular cartilage between weeks 8 and 23 of prenatal development. Acta vet. Brno, 55, 1986: 227-246.

HORKÝ, D.: Submicroscopic structure of bovine articular cartilage in prenatal and early postnatal period. Acta vet. Brno, 56, 1987: 3-18.

HORKYY, D.: The ultrastructure of articular cartilage in the prenatal pig. Acta vet. Brno, 58, 1989: 143-174.

HORKY, D.: Submicroscopic structure of articular cartilage in human embrya six to eleven weeks old. Acta vet. Brno, 60, 1991a: 15-30.

HORKÝ, D.: Submicroscopic structure of human articular cartilage in the period between 19 to 38 weeks after fertilization. Acta vet. Brno, 60, 1991b: 111-126.

HORKÝ, D.: The submicroscopic structure of articular cartilage in swine in the early postnatal period. Acta vet. Brno, 60, 1991d: 323-334.

HORKÝ, D.: Submikroskopická stavba kloubní chrupavky dospělého prasete. Scripta medica, 64, $1991 \mathrm{f}: 177$.

HORKÝ, D.: The submicroscopic structure of articular cartilage in the adult pig. Acta vet. Brno, 62, 1993: 9-18.

LUST, G.-PRONSKY, W.-SHERMAN, D.: Biochemical and ultrastructural observations in normal and degenerative canine articular cartilage. J. vet. res., 33, 1972: 2429-2440.

LUST, G.-SHERMAN, D. M.: Metabolic and ultrastructural studies on articular cartilage of developing canine hip joints. Cornell Vet., 63, 1973: 94-104.

MAROUDAS, A.: Physico-chemical properties of articular cartilage. In: Adult articular cartilage. M. A. R. Freeman, Alden Press, Oxford 1973.

McCONAILL, M. A.: The movements of bones and joints. The mechanical structure of articulating cartilage. J. Bone Jt. Surg., 33B, 1951: 25-257.

McCUTCHEN, C. W.: Boundary lubrication by synovial fluid: demonstration and possible osmotic explanation. Fed. Procd., 25, 1966: 1061.

NAKANO, T.-AHERNE, F. X.-THOMPSON, J. R.: Changes in swine knee articular during growth. Can. J. Anim. Sci., 59, 1979a: 167-179. 
NAKANO, T.-AHERNE, F. X.-THOMPSON, J. R.: Effects of feed restriction, sex and diethylstilbestrol on the occurrence of joint lesions with some histological and biochemical studies on the articular cartilage of growingfinishing swine. Can. J. Anim. Sci., 59, 1979b: 491-502.

PALFREY, A. J.-DAVIES, D. V.: The fine structure of chondrocytes. J. Anat., 100, 1966: 213-228.

PERRIN, W. R.-AHERNE, F. X.-BOWLAND, J. P.-HARDIN, R. T.: Effects of age, breed and floor type on the incidence of articular cartilage lesions in pigs. Can. J. Anim. Sci., 58, 1978: 129-138.

SHELDON, H.-KIMBALL, F. B.: Studies on cartilage. III. The occurrence of collagen within vacuoles of the Golgi apparatus. J. Cell Biol., 12, 1962: 559-613.

SILBERGER, R.-HASLER, M.-LESKER, P.: Ultrastructure of articular cartilage of achondroplastic mice. Acta Anat. (Basel), 96, 1976: 162-175.

STOCKWELL, R. A.-MEACHIM, G.: The chondrocytes. In: Adult articular cartilage. 2nd edition. Ed.: M. A. R. Freeman, London, Pitman Medical 1979.

SWANN, D. A.-BLOCH, K. J.-SWINDELL, D.-SHORE, E.: The lubricating activity of human synovial fluid. Arthritis Rheum., 27, 1984: 552-557.

WEISS, C.-ROSENBERG, L.-HELFERT, A. J.: An ultrastructural study of normal young adult human articular cartilage. J. Bone Jt. Surg., 50A, 1968: 663-674.

WILTERBERGER, H.-LUST, G.: Ultrastructure of canine articular cartilage: comparison of normal and degenerative (osteoarthritic) hip joints. Am. J. vet. Res., 36, 1975: 727-740.

WOLF, J.: Function of chondral membrane on surface of articular cartilage from point of view of its mechanical resistance. Folia morphol. (Prague), 23, 1975: 77-87. 
Horký D.: The submicroscopic structure... pp. 41-48

Plate V.

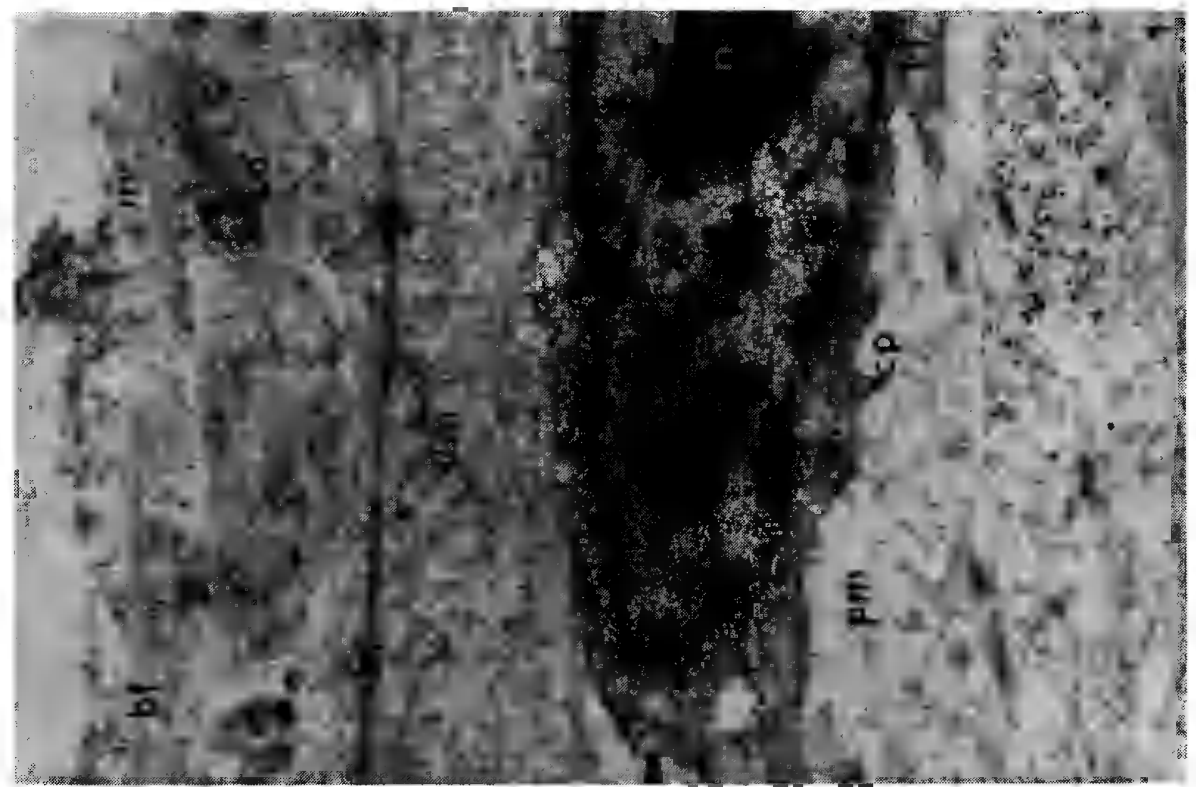

Fig. 1: Surface layer of articular cartilage 56 days after fertilization. Nucleus of a chondroblast $(\mathrm{N})$, nucleolus (n). Cisternae of agranular endoplasmic reticulum (E), mitochondria (M), occasional glycogen granules $(\mathrm{g})$. Projections of the cell membrane $(\mathrm{cp})$ extended into the pericellular matrix $(\mathrm{pm})$. Intercellular matrix (Im). Bundles of aperiodic filaments (bf), chondrosynovial membrane (m), cell detritus (cd). $\times 16000$.

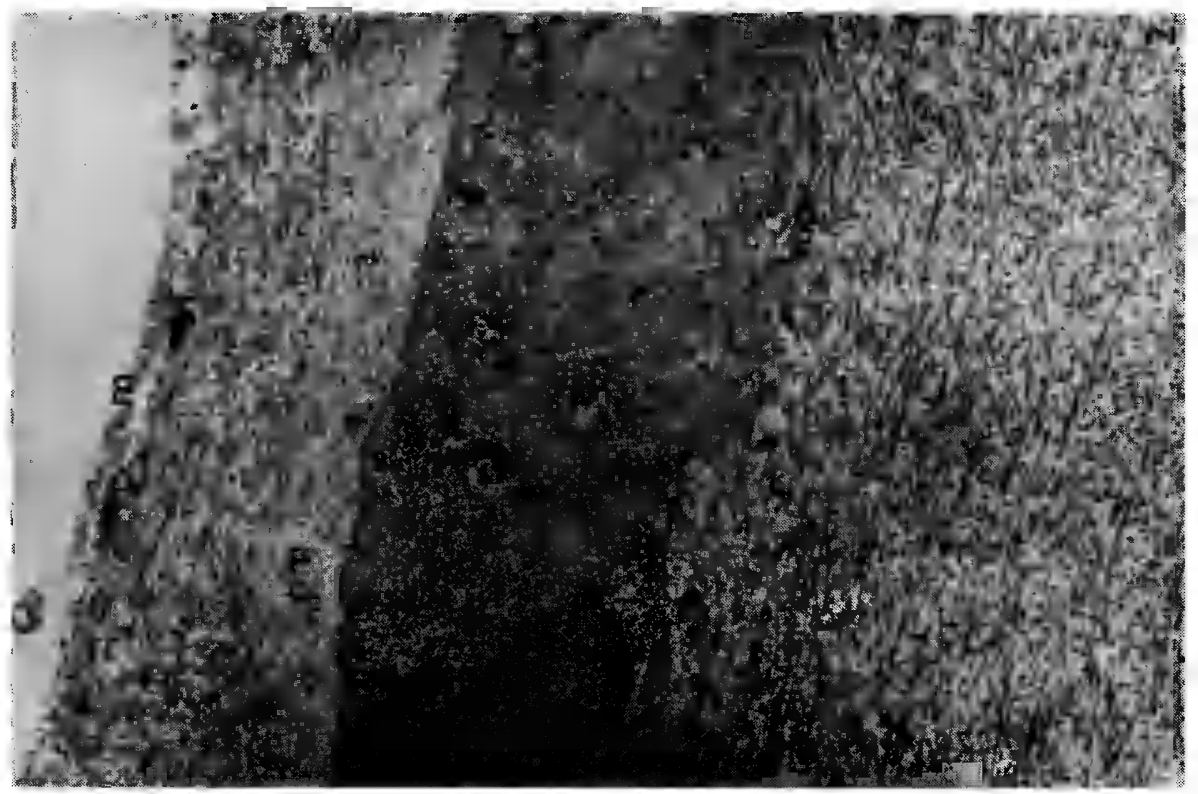

Fig. 2: Surface layer of articular cartilage at 33 days after birth. Chondrosynovial membrane (m), cross sections through bundles of aperiodic filaments (bf). Numerous cisternae of granular endoplasmic reticulum (E), minute smooth vesicles (v), Golgi field (G), transport vacuoles (T), mitochondria (M). Projections of the cell membrane (cp), pericellular matrix (pm) with aperiodic fibrils (a) $\times 12500$. 


\section{Plate VI.}

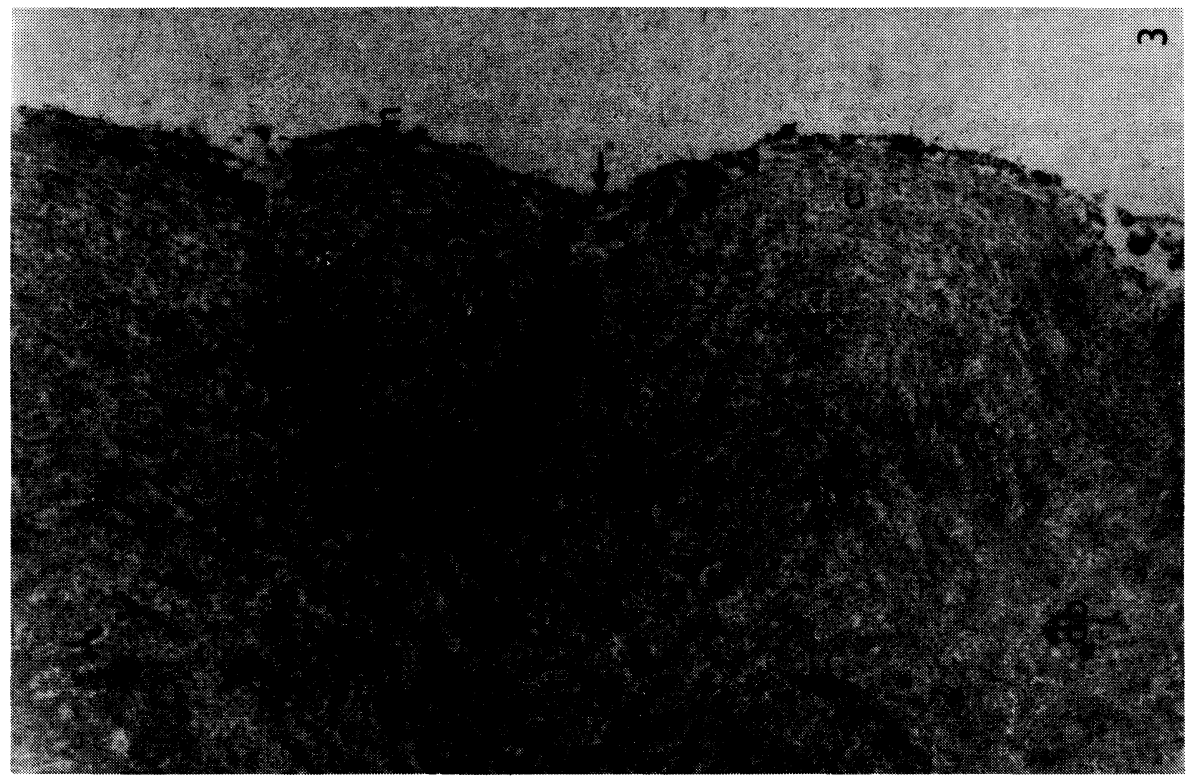

Fig. 3: Surface layer of articular cartilage at 6 years of age. Chondrosynovial membrane $(\mathrm{m})$ with granular material filling surface depressions $(\rightarrow)$. Bundles of collagen fibres $(\mathrm{c})$, dark bodies $(\mathrm{db}) . \times 16000$.

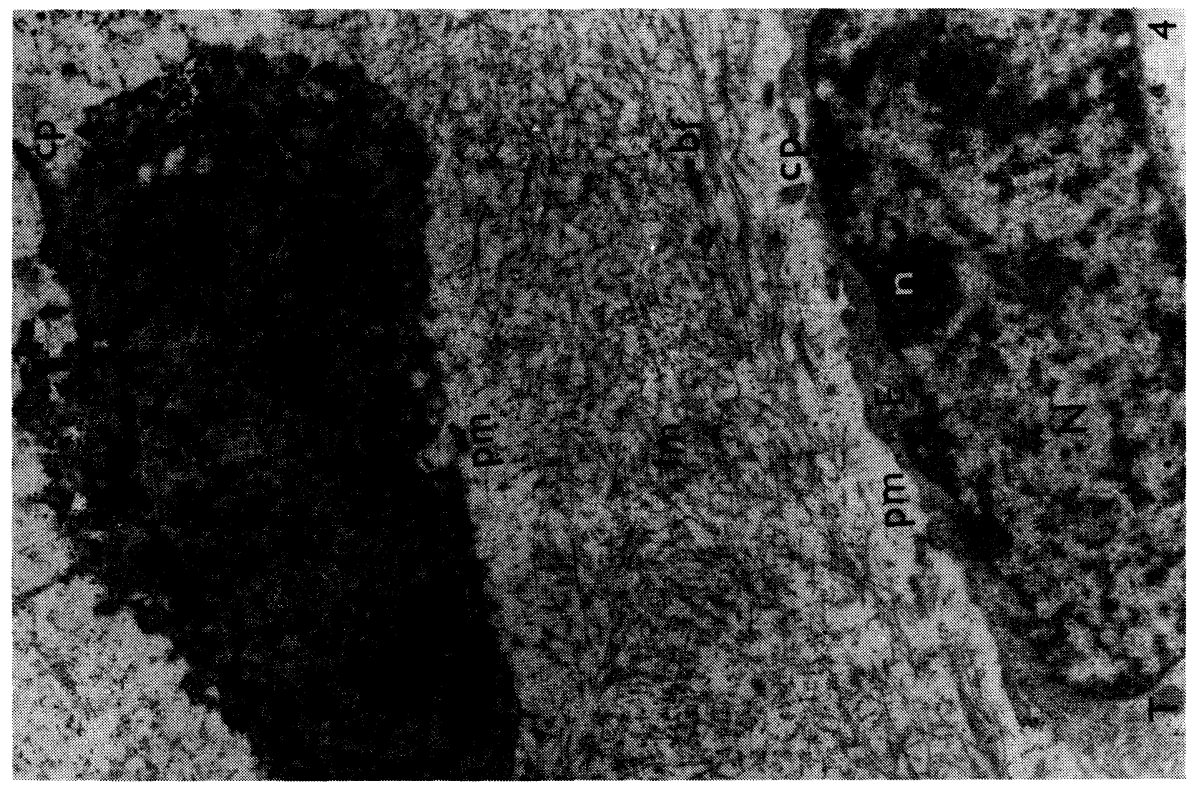

Fig. 4: Part of the middle layer of articular cartilage at 56 days after fertilization. Nucleus $(\mathrm{N})$, nucleolus of reticular type (n). Cisternae of granular endoplasmic reticulum (E), transport vacuoles (T), mitochondria (M), glycogen aggregates (g). Projections of the cell membrane (cp) extended into pericellular matrix (pm). Lacunae in the intercellular matrix separated by bundles of aperiodic filaments (bf). $\times 12000$. 


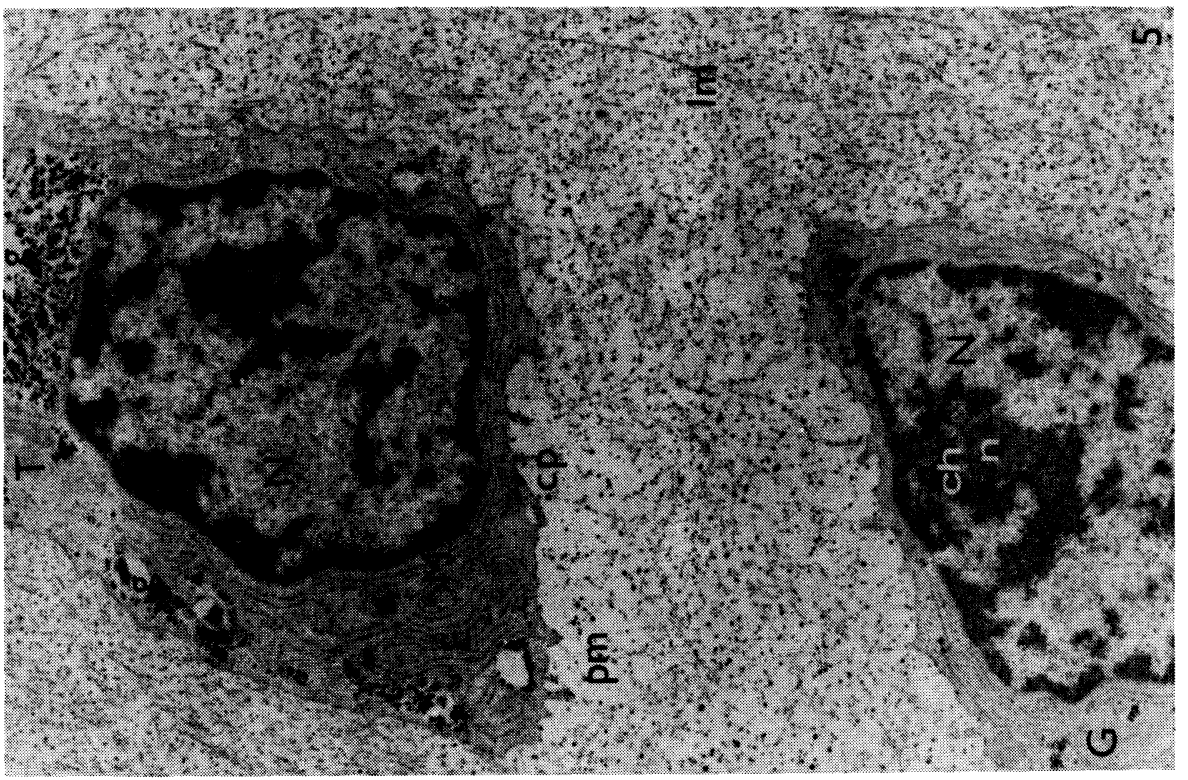

Fig. 5: Middle layer of articular cartilage at 33 days after fertilization. A pair of chondrocytes. Nucleus (N), nucleolus of reticular type (n) with perinucleolar chromatin (ch). Cisternae of granular endoplasmic reticulum (E), mitochondria (M), transport vacuoles $(\mathrm{T})$, Golgi apparatus $(\mathrm{G})$, glycogen deposits $(\mathrm{g})$. Projections of the cell membrane $(\mathrm{cp})$, pericellular matrix $(\mathrm{pm})$, intercellular matrix with collagen fibrils $(\mathrm{Im}) . \times 16000$.

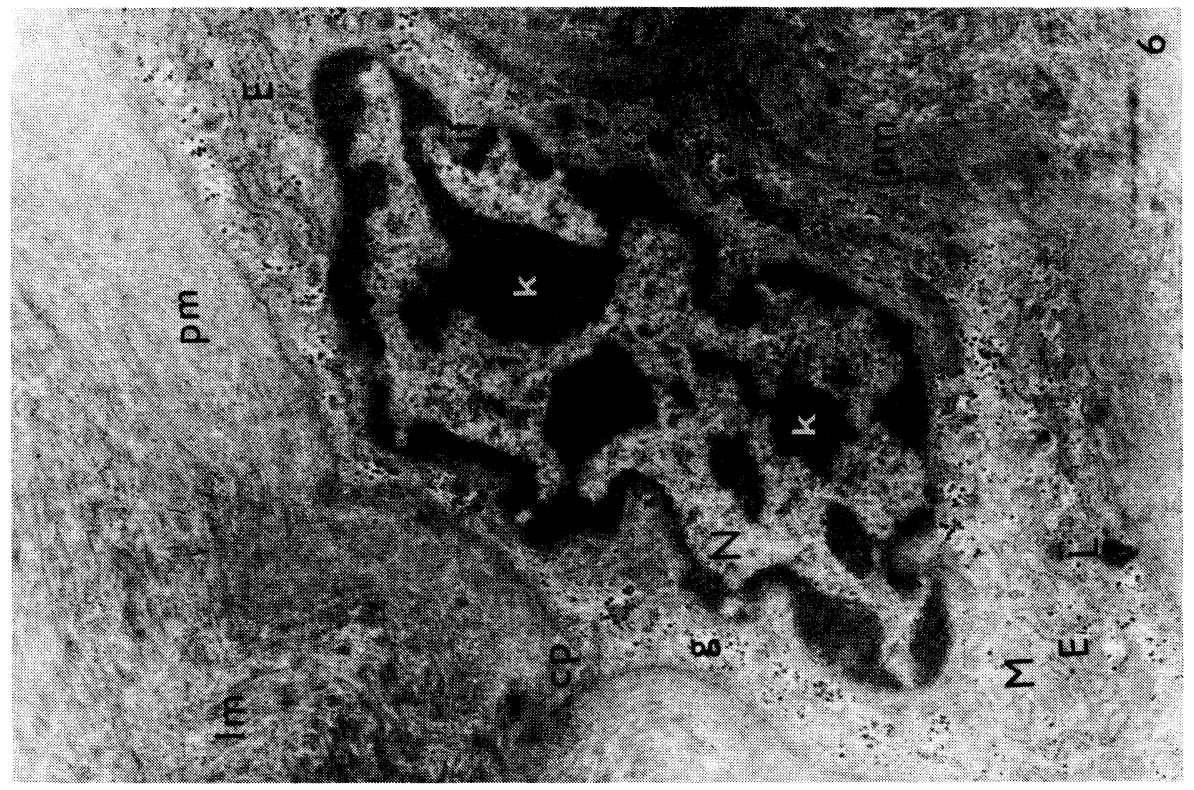

Fig. 6: Middle layer of articular cartilage at 6 years of age. Nucleus $(\mathrm{N})$ with large karyosomes $(\mathrm{k})$ in a chondrocyte. Granular endoplasmic reticulum (E), mitochondria (M), lysosomes (L), small clusters of glycogen (g), bundles of intracytoplasmic filaments (if) around the nucleus. Projections of the cell membrane (cp), pericellular matrix with densely accumulated filaments (pm). Collagen fibrils as a ,basket" for a chondrocyte in the intercellular matrix (Im). $\times 16000$. 


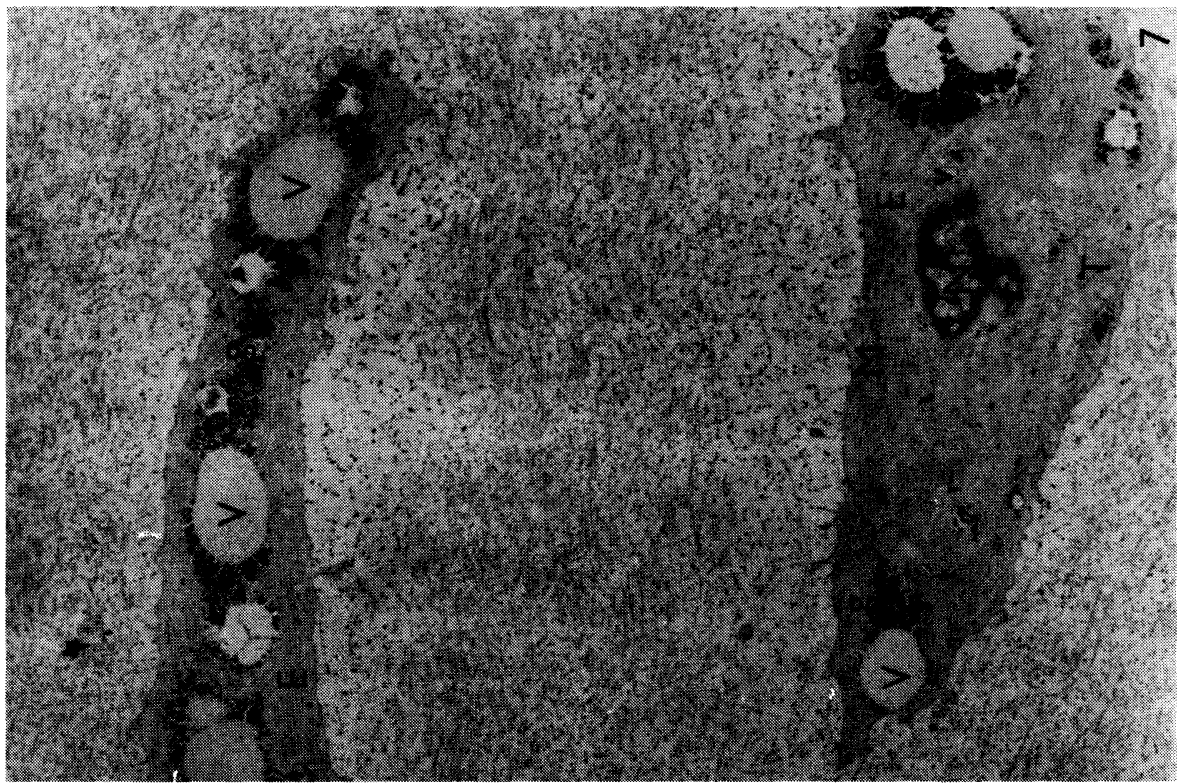

Fig. 7: Part of the deep layer of articular cartilage at 33 days after birth. Nucleus $(\mathrm{N})$ of sickle-shaped chondorocytes. In the cytoplasm, numerous narrow cisternae of granular endoplasmic reticulum (E), small mitochondria (M), transport vacuoles (T), numerous smooth vesicles (v). Large deposits of glycogen $(\mathrm{g})$, lipid vacuoles (V). $\times 8500$.

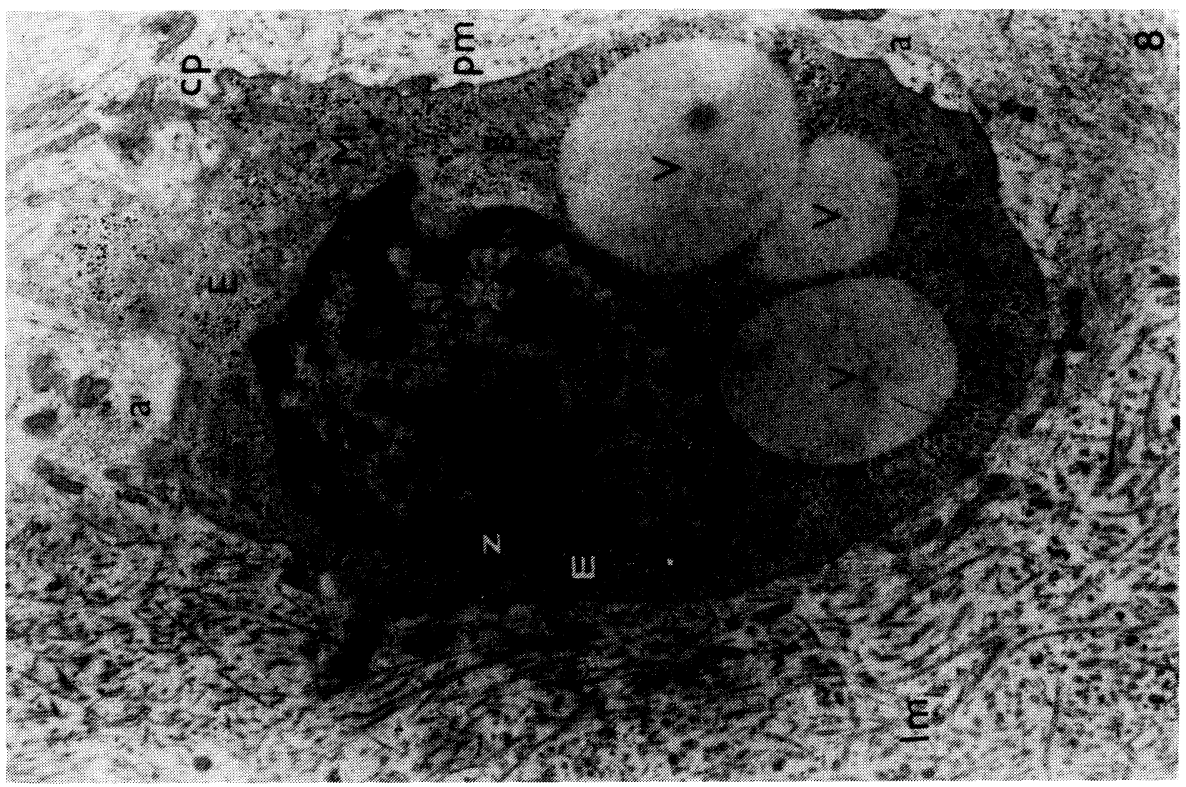

Fig. 8: Chondrocyte in the deep layer of articular cartilage at 4 years of age with part of the intercellular matrix. Nucleus (N), zonula nucleum limitans (z), short cisternae of granular endoplasmic reticulum (E), mitochondria (M), scattered glycogen granules $(\mathrm{g})$ and large lipid vacuoles $(\mathrm{V})$. Cell membrane projections (cp), pericellular matrix (cp) with aperiodic fibrils (a). Intercellular matrix (Im). $\times 16000$. 